UDC 378.016:004

Serhii A. Lupenko

Doctor of Technical Science, Professor, Professor of the Computer Systems and Networks Department Ternopil Ivan Pul'uj National Technical University, Ternopil, Ukraine

ORCID ID 0000-0002-6559-0721

lupenko.san@gmail.com

Volodymyr V. Pasichnyk

Doctor of Technical Science, Professor, Professor of the Information Systems and Networks Department

Lviv Polytechnic National University, Lviv, Ukraine

ORCID ID 0000-00002-5231-6395

vpasichnyk@gmail.com

Nataliia E. Kunanets

Doctor of Sciences from Social Communications, Professor of the Information Systems and Networks

Department

Lviv Polytechnic National University, Lviv, Ukraine

ORCID ID 0000-0003-3007-2462

nek.lviv@gmail.com

\title{
AXIOMATIC-DEDUCTIVE STRATEGY FOR IT DISCIPLINE CONTENT FORMATION
}

\begin{abstract}
The paper presents the axiomatic-deductive strategy of organizing the content of an academic discipline with the help of ontological approach in the e-learning systems in the field of information technologies. The authors have taken into account that the necessary property of the system of axiomatic statements is their consistency. On the basis of axiomatic-deductive strategy, new approaches to the formation of the discipline content are proposed. It is proved that the system of true statements of an academic discipline is based on its terminology-conceptual apparatus, in particular, axiomatic statements. The developed mathematical structures that describe the axiomatic-deductive substrategy of the organization of the academic discipline general statements and the taxonomically oriented substrategy of the deployment of the academic discipline content are presented in the article. This ensures the transition from the content form of representation of the set of statements of the academic discipline to its presentation by means of artificial languages of mathematical logic. The use of descriptive logic ensures the formalization of the procedure for displaying an axiomatic informal system in an axiomatic formal system. The mathematical structures describe and detail the abstract logical-semantic core of the academic discipline in the form of a group of axiomatic systems. It is noted that the basic core of the content of academic discipline contains its basic concepts and judgments. This ensures a strictly logical transition from abstract general concepts and statements to the concepts and assertions of the lower level of universality and abstraction. It is noted that in order to accommodate the content of an academic discipline is advisable to develop a taxonomically oriented sub-strategy based on the multiple application of operations of general concept division. The mathematical structures allow for analysis of a generalized structure of interactions between the verbal level of the description of the academic discipline subject area, the formal level of description of the subject area and the description of the subject area at the level of computer ontology, which is implemented through the formalization, interpretation, encoding and decoding in the computer-ontology development environment. As an example of the application of the proposed axiomatic-deductive strategy, the elements of the glossary and taxonomies of the concepts of the discipline "Computer Logic", which are embodied in the Protégé environment with the help of OWL ontology description language have been developed.
\end{abstract}

Keywords: e-learning system; axiomatic-deductive system; ontology; ontological approach. 


\section{INTRODUCTION}

The development of modern information technologies for the educational sector substantially intensifies and improves the quality of the educational process. Today, there are a large number of different information systems, technologies, portals for educational services. Scientific journals have published a huge number of articles related to e-learning systems [1-6]. The basis of quality e-learning systems is their high-quality content. Unfortunately, the vast majority of e-learning systems and technologies are not focused on creating quality content as an expression of the semantic space of discipline by means of natural language. Known approaches to the organization of the content of academic disciplines in the field of information technology, implemented in a number of existing elearning systems, are mainly based on intuitive, heuristic paradigm, rather than on a clear formalized strategy using an adequate mathematical apparatus, which often leads to low quality content of electronic courses. Therefore, the development of mathematical models, methods and software for the formation of high quality content is an important scientific and applied problem that needs to be solved.

State of the problem study. One approach to the development of high-quality content of a discipline is an ontological approach [7-11]. An ontological approach involves the development of an ontology of a subject area, which is studied by the corresponding academic discipline. According to the generally accepted definition of ontology, an explicit machineinterpretive specification of conceptualization is understood. Conceptualization is the process of constructing a conceptual model of a subject area. The success of all the subsequent stages of constructing the ontology of the subject area of the academic discipline and onto-oriented (onto-based) intellectualized systems of e-learning depends exactly on the correct, qualitative conceptualization.

Works [12, 13] have developed a generalized structure of the axiomatic-deductive strategy of the organization of academic content, which includes three of its subtrategies, that is, the axiomatic-deductive subtrategy of the organization of the fundamental terminologicalconceptual apparatus of the academic discipline, the axiomatic-deductive subtrategy of the organization of general statements of the academic discipline and the taxonomically oriented substrategy of the deployment of the academic discipline content. These articles propose that the semantic space of the academic discipline be presented as a connection of its logicalsemantic core, organized by the axiomatic-deductive strategy, and the periphery of the semantic space of the academic discipline. In the structure of the logical-semantic core of the academic discipline its basic components are identified as an abstract logic-semantic core of the academic discipline and a metadisciplinary logic-semantic core of the academic discipline. The axiomatic-deductive strategy of organizing academic content ensures the presence of a clear, compact, ordered structure of organization of knowledge about the subject area of the discipline, which gives it significant advantages over non-axiomatic strategies. In the article [12], the mathematical structures of the axiomatic-deductive strategy of the organization of the terminology-conceptual apparatus of an academic discipline are highlighted.

In this paper the mathematical structures are created which describe and detail the abstract logical-semantic core of the academic discipline in the form of a group of axiomatic systems, that is: axiomatic informal systems of general statements of the academic discipline in a verbal form, formal axiomatic systems of general statements of the academic discipline, axiomatic systems of general statements of the academic discipline in the machineinterpretative form. Also, the purpose of this article is to implement the elements of the proposed axiomatic-deductive strategy for organizing the contents of the discipline "Computer Logic" in the Protégé environment, using the language of describing the ontology of OWL. 


\section{RESULTS}

\subsection{Axiomatic-deductive substrategy of the organization of general truth statements of the academic discipline in the systems of electronic learning}

\section{The set of general truth statements in the discipline in a content form}

The first stage of the axiomatic-deductive strategy of organizing the set of true statements of the academic discipline is the formation (selection) of the set $\mathbf{A S}_{V}=\left\{S_{V_{1}}, S_{V_{2}}, \ldots, S_{V_{M}}\right\}$ axiomatic (fundamental) statements (judgments, propositions) in a natural language with a finite alphabet $\mathbf{A l S}_{V}$, which do not require proofs within the subject area studied by the corresponding academic discipline. A necessary property of the system of axiomatic statements is their consistency. In addition, it is important that the axiomatic statements of the academic discipline be independent of each other, namely that no axiomatic statement can be denoted by the set of the remaining axiomatic statements.

The system of true statements of the academic discipline is based on its terminologyconceptual apparatus, in particular, axiomatic statements $\mathbf{A} \mathbf{S}_{V}=\left\{S_{V_{1}}, S_{V_{2}}, \ldots, S_{V_{M}}\right\}$ can be considered as functions on atomic general concepts $\mathbf{B C}_{V}=\left\{C_{V_{1}}, C_{V_{2}}, \ldots, C_{V_{N}}\right\}$ academic discipline, namely as identical truthful predicates:

$$
S_{V_{m}}=f_{m}\left(C_{V_{1}}, C_{V_{2}}, \ldots, C_{V_{N}}\right), m=\overline{1, M} .
$$

Alphabet $\mathbf{A l S}_{V}$ as its subset contains the alphabet $\mathbf{A l C}_{V}$.

The next stage of the axiomatic-deductive strategy of organizing the system of statements of a academic discipline is the formation of a set Ruls_for_S $=\left\{R S_{V_{1}}, R S_{V_{2}}, \ldots, R S_{V_{J}}\right\}$ logical rules of deduction from the set of axiomatic statements $\mathbf{A} \mathbf{S}_{V}=\left\{S_{V_{1}}, S_{V_{2}}, \ldots, S_{V_{M}}\right\}$ derivatives of truthful statements (theorems) $\mathbf{D S}_{V}=\left\{S_{V_{M+1}}, S_{V_{M+2}}, \ldots, S_{V_{M+G}}\right\}$. Derivative statements $\quad \mathbf{D S}_{V}=\left\{S_{V_{M+1}}, S_{V_{M+2}}, \ldots, S_{V_{M+G}}\right\}$ together with axiomatic statements $\mathbf{A} \mathbf{S}_{V}=\left\{S_{V_{1}}, S_{V_{2}}, \ldots, S_{V_{M}}\right\}$ form a set of truthful statements of the abstract content core of the discipline $\mathbf{T S} \mathbf{S}_{V}=\mathbf{A} \mathbf{S}_{V} \cup \mathbf{D S}_{V}=\left\{S_{V_{1}}, S_{V_{2}}, \ldots, S_{V_{M+G}}\right\}$.

Preferably, the logical output rules have certain logical tautologies that can be presented as relations given on a set of highly abstract statements $\mathbf{T S}_{V}=\left\{S_{V_{1}}, S_{V_{2}}, \ldots, S_{V_{M+G}}\right\}$ of an academic discipline and can be formally represented in this form:

$$
\frac{S_{V_{1}}, S_{V_{2}}, \ldots, S_{V_{M}}}{S_{V_{g+M}}}\left(R S_{V_{j}}\right), g \in \overline{1, G}, j \in \overline{1, J} .
$$

In this case, the derivative statement $S_{V_{g+M}}$ is a direct consequence of axiomatic statements $S_{V_{1}}, S_{V_{2}}, \ldots, S_{V_{M}}$ by the rule $R S_{V_{j}}$.

The group of the statements of the academic discipline by means of a natural language can be described as an axiomatic non-formal system that can be represented in the form of such a structure:

$$
\mathbf{A S}_{S V}=\left\{\mathbf{A l S}_{V}, \mathbf{T S}_{V}, \mathbf{A S} \mathbf{S}_{V}, \mathbf{R u l s \_ f o r} \_\mathbf{S}_{V}\right\} .
$$

The conceptual scheme of the axiomatic-deductive substrate of the organization of the fundamental general terminology-conceptual apparatus of the academic discipline is given in Figure 1. 


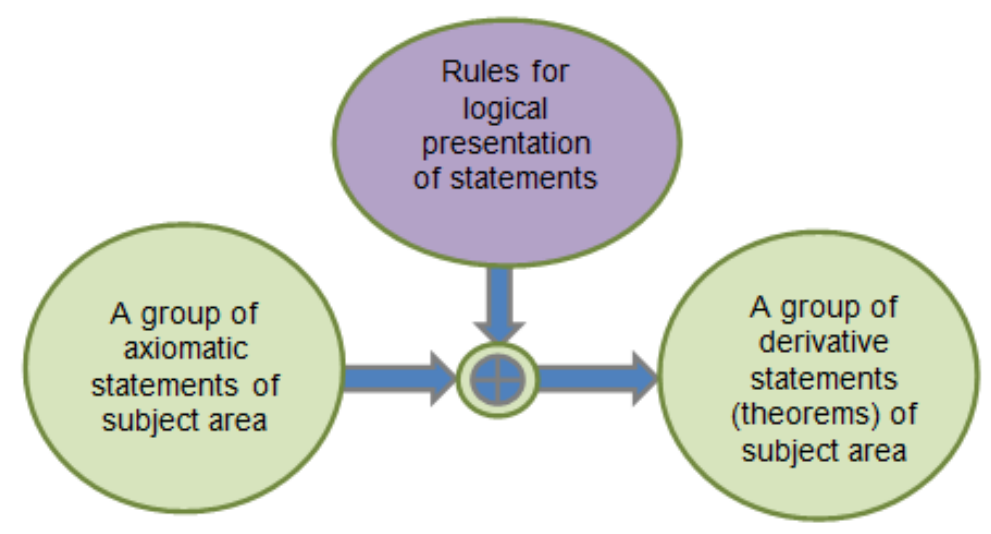

Fig. 1 Conditional scheme of axiomatic-deductive substrategy of organization of a group of general truthful statements of an academic discipline

\section{The set of general truthful statements of an academic discipline as a formal axiomatic system}

The transition from the content form of representation of the set of statements of an academic discipline to its presentation by means of artificial languages of mathematical logic, that is, descriptive logic, is carried out through its formalization - the procedures for displaying the axiomatic informal system in the axiomatic formal system, which is given as such a four:

$$
\mathbf{A S} \mathbf{S F}_{S F}=\left\{\mathbf{A l S}_{F}, \mathbf{T S}_{F}, \mathbf{A} \mathbf{S}_{F}, \text { Ruls_for_S } \mathbf{S}_{F}\right\},
$$

where $\mathbf{A l C}_{F}$ is the alphabet of the formal language of the logic of predicates of the first order; from the elements of the alphabet $\mathbf{A l C}_{F}$ correctly formed formulas (formulas) of corresponding logic system are created; $\mathbf{T S} \mathbf{S}_{F}=\left\{S_{F_{1}}, S_{F_{2}}, \ldots, S_{F_{M+G}}\right\}$ - the set of all correctly created formulas in the alphabet $\mathbf{A I C}{ }_{F}$, which are mutually unequivocally consistent with the statement of the academic discipline in the natural language $\mathbf{T S}_{V}=\left\{S_{V_{1}}, S_{V_{2}}, \ldots, S_{V_{M+G}}\right\}$; $\mathbf{A S}_{F}=\left\{S_{F_{1}}, S_{F_{2}}, \ldots, S_{F_{M}}\right\}$ - a set of formal axioms that are mutually unequivocally consistent with the axiomatic statement of $\mathbf{A S _ { V }}=\left\{S_{V_{1}}, S_{V_{2}}, \ldots, S_{V_{M}}\right\}$ and is a subset $\mathbf{T S}_{F}\left(\mathbf{A S}_{F} \subset \mathbf{T S} \mathbf{S}_{F}\right)$; Ruls_for_S $\mathbf{S}_{F}=\left\{R S_{F_{1}}, R S_{F_{2}}, \ldots, R S_{F_{J}}\right\}$ is the set of formally-logical rules (operations) of the derivative from the set $\mathbf{A S}_{F}=\left\{S_{F_{1}}, S_{F_{2}}, \ldots, S_{F_{M}}\right\}$ new derivatives of correctly created formulas $\mathbf{D S}_{F}=\left\{S_{F_{M+1}}, S_{F_{M+2}}, \ldots, S_{F_{M+G}}\right\}$ of an educational discipline. From the foregoing follows the following relation: $\mathbf{T S}_{F}=\mathbf{A S}_{F} \cup \mathbf{D S} \mathbf{S}_{F}=\left\{S_{F_{1}}, S_{F_{2}}, \ldots, S_{F_{M+G}}\right\}$. In contrast to the logical derivation (outcome) of derivative statements in the informal axiomatic system of content organization, where "logical proof" is interpreted as a complete contex inference that is an integral part of the real thinking of a person, namely, it is such an inference, in the process of which of the judgments-findings by using logical rules of thinking, they obtain a conclusion - new judgments, which are expressed by means of natural language, in formal axiomatic systems, "logical proof " is understood as simple manipulation (operations) over symbols and sequences of symbols (formulas) of a certain artificial language according to the pre-defined strictly given rules. The conclusion obtained by means of such a "logical proof " in the narrow sense is the usual formula - the sequence (combination) of symbols of the alphabet of some artificial language. 
The procedure of formalizing the group of the statements of the academic discipline will be presented as such a two $\mathbf{F o r m a l}_{\mathbf{S}}=\left(\mathbf{T S}_{F}, f_{S}^{\text {Form }}(\cdot)\right)$, consisting of a set of correctly created formulas $\mathbf{T} \mathbf{S}_{F}$ and function of formalization $f_{S}^{F o r m}(\cdot)$, which is given on the set $\mathbf{T} \mathbf{S}_{V}$, with a range of values $\mathbf{T S} \mathbf{S}_{F}$. That is, the procedure of formalizing of a certain statement $S_{V_{n}}$ iз $\mathbf{T S} \mathbf{S}_{V}$ is determined by comparing it with the function of formalization $f_{S}^{F o r m}(\cdot)$, a certain correctly created formula $S_{F_{n}}$ iз $\mathbf{T S} S_{F}$, that is:

$$
\forall S_{V_{n}} \in \mathbf{T S}_{V}, \exists\left(S_{F_{n}} \in \mathbf{T} \mathbf{S}_{F}\right) \text {, that } C_{F_{n}}=f_{S}^{F o r m}\left(C_{V_{n}}\right) \text {. }
$$

On the other hand, the transition from the formal axiomatic system $\mathbf{A S} \mathbf{S}_{S F}=\left\{\mathbf{A l S}_{F}, \mathbf{T S}_{F}, \mathbf{A} \mathbf{S}_{F}, \mathbf{R u l s} \_\right.$for_S $\left.\mathbf{S}_{F}\right\}$ to the axiomatic informal system $\mathbf{A S}_{S V}=\left\{\mathbf{A I S}_{V}, \mathbf{T S}_{V}, \mathbf{A} \mathbf{S}_{V}\right.$, Ruls_for_S $\left.\mathbf{S}_{V}\right\}$ is accomplished through the interpretation procedure, which is given as a two $\mathbf{I}_{S}=\left(\mathbf{T S}_{V}, f_{S}^{I}().\right)$ and consists of a set $\mathbf{T} \mathbf{S}_{V}$ and function of interpretation $f_{S}^{I}(\cdot)$, which is given on the set $\mathbf{T S}_{F}$ with an range of values $\mathbf{T S}_{V}$. That is, the procedure of interpreting of some correctly created formula $S_{F_{n}}$ from $\mathbf{T S}_{F}$ is given by comparing it with the function of interpretation $f_{S}^{I}(\cdot)$, a certain statement $S_{V_{n}}$ is $\mathbf{T S}_{V}$, that is:

$$
\forall S_{F_{n}} \in \mathbf{T S}_{F}, \exists\left(S_{V_{n}} \in \mathbf{T} \mathbf{S}_{V}\right) \text {, що } S_{V_{n}}=f_{S}^{I}\left(S_{F_{n}}\right) \text {. }
$$

\section{The group of general truthful statements of an academic discipline in machine- interpreted form}

The transition from the submission of a group of statements of an academic discipline in the form of a formal axiomatic system before its submission by means of development of elearning systems is performed by the application of coding procedure, which reflects the axiomatic formal system in machine-interpreted form, which can be represented as such four:

$$
\mathbf{A S} \mathbf{S}_{S E L}=\left\{\mathbf{A} \mathbf{I S} \mathbf{E L}_{E L}, \mathbf{T} \mathbf{S}_{E L}, \mathbf{A S} \mathbf{S}_{E L}, \mathbf{R u l s \_ f o r} \_\mathbf{S}_{E L}\right\} \text {, }
$$

where $\mathbf{A l C}_{E L}$ is the alphabet of machine-interpreted language of describing statements in elearning systems, for example, Moodle; $\mathbf{T S}_{E L}=\left\{S_{E L_{1}}, S_{E L_{2}}, \ldots, S_{E L_{M+G}}\right\}$ - the set of all correctly created formulas in the alphabet $\mathbf{A l C} \mathbf{C}_{E L}$, mutually unequivocally consistent to the statement of the academic discipline in the natural language $\mathbf{T S}_{V}=\left\{S_{V_{1}}, S_{V_{2}}, \ldots, S_{V_{M+G}}\right\} ; \mathbf{A} \mathbf{S}_{E L}=\left\{S_{E L_{1}}, S_{E L_{2}}, \ldots, S_{E L_{M}}\right\}$ - the set of axiom of the alphabet of the machine-interpreted language of describing statements in the systems of e-learning, which are mutually unequivocally consistent with the axiomatic sratements from $\mathbf{A S}_{V}=\left\{S_{V_{1}}, S_{V_{2}}, \ldots, S_{V_{M}}\right\} \quad$ and $\quad$ is $\quad$ a r subset $\mathbf{T S}_{E L}\left(\mathbf{A S} \mathbf{S}_{E L} \subset \mathbf{T S} \mathbf{S}_{E L}\right)$; Ruls_for_S $\mathbf{S}_{E L}=\left\{R S_{E L_{1}}, R S_{E L_{2}}, \ldots, R S_{E L_{J}}\right\}$ is the set of machineinterpreted logical rules (operations) of a derivative from the set $\mathbf{A S} \mathbf{S}_{E L}=\left\{S_{E L_{1}}, S_{E L_{2}}, \ldots, S_{E L_{M}}\right\}$ new derivatives of machine-interpreted formulas $\mathbf{D S}_{E L}=\left\{S_{E L_{M+1}}, S_{E L_{M+2}}, \ldots, S_{E L_{M+G}}\right\}$ in the environment of e-learning systems.

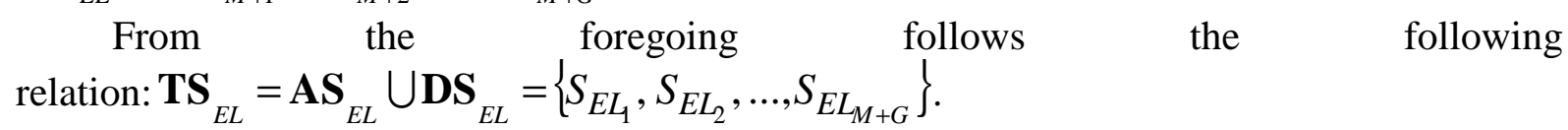


The coding procedure will be represented as such $\mathbf{E L C O d}=\left(\mathbf{T S}_{E L}, f_{S}^{\operatorname{Cod}}(\cdot)\right)$, consisting of a set of correctly created formulas $\mathbf{T S}_{E L}$ in the syntax of the language of describing the statements of the e-learning system and the coding function $f_{S}^{C o d}(\cdot)$, which is given on the set $\mathbf{T S}_{F}$, with an range of values $\mathbf{T S}_{E L}$. That is, the coding procedure of some correctly created formula $S_{F_{n}}$ is $\mathbf{T S} S_{F}$ is given by comparing it with the coding function $f_{S}^{\text {Cod }}(\cdot)$, a certain expression $S_{E L_{n}}$ from $\mathbf{T S} \mathbf{S}_{E L}$, that is:

$$
\forall S_{F_{n}} \in \mathbf{T S}_{F}, \exists\left(S_{E L_{n}} \in \mathbf{T} \mathbf{S}_{E L}\right), \quad \text { that } \quad S_{E L_{n}}=f_{S}^{\operatorname{Cod}}\left(S_{F_{n}}\right) \text {. }
$$

The transition from the machine-realization system $\mathbf{T}_{S E L}=\left\{\mathbf{A I S}_{E L}, \mathbf{T S}_{E L}, \mathbf{A \mathbf { S } _ { E L }}, \mathbf{R u l s} \_\right.$for_S $\left.\mathbf{S}_{E L}\right\}$ to the axiomatic formal system $\mathbf{T}_{S F}=\left\{\mathbf{A l S}_{F}, \mathbf{T S}_{F}, \mathbf{A} \mathbf{S}_{F}\right.$, Ruls_for_S $\left.\mathbf{S}_{F}\right\}$ is accomplished through the decoding procedure, which is set as two $\mathbf{E L D e c o d}=\left(\mathbf{T S}_{F}, f_{S}^{\text {Decod }}(\cdot)\right)$. Decoding function $f_{S}^{\text {Decod }}(\cdot)$, which is given on the set $\mathbf{T S}_{E L}$ with a range of values $\mathbf{T S}_{F}$. That is, the procedure of decoding the expression $S_{E L_{n}}$ from $\mathbf{T S}_{E L}$ is determined by comparing it with the decoding function $f_{S}^{\text {Decod }}($.$) a certain correctly created formula S_{F_{n}}$ i3 $\mathbf{T S}{ }_{F}$, that is:

$$
\forall S_{E L_{n}} \in \mathbf{T S}_{E L}, \exists\left(S_{F_{n}} \in \mathbf{T S}_{F}\right) \text {, що } S_{F_{n}}=f_{S}^{\text {Decod }}\left(S_{E L_{n}}\right) \text {. }
$$

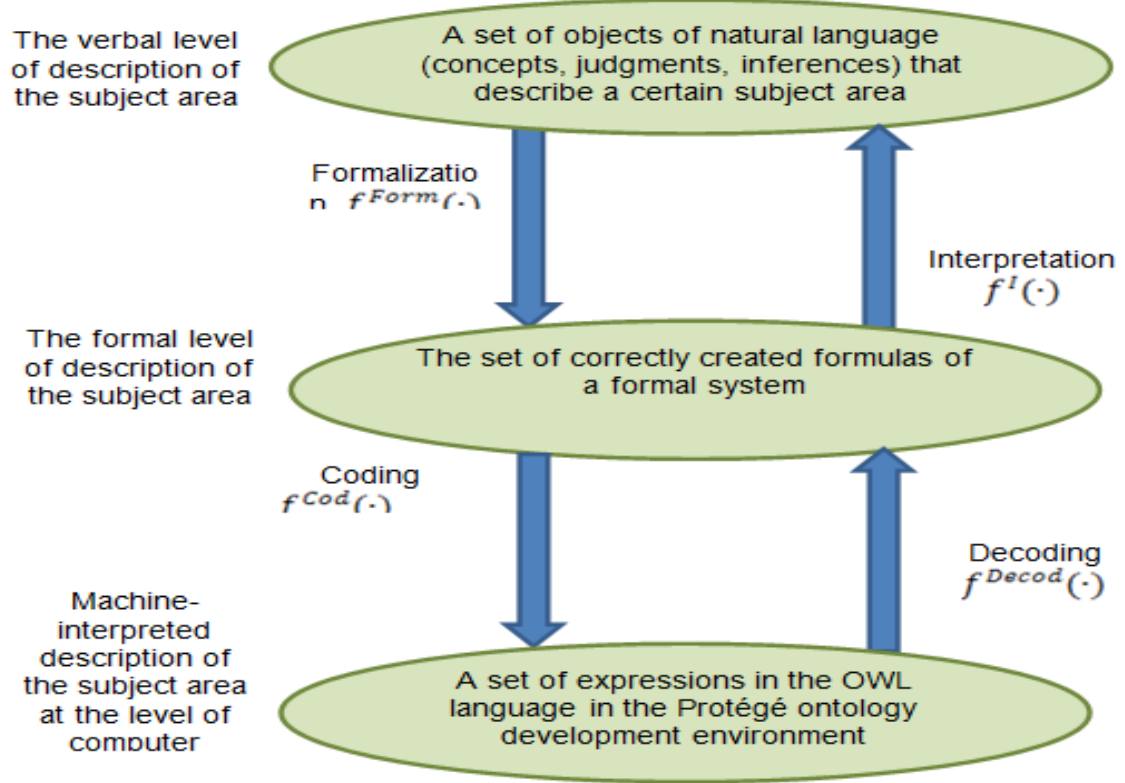

Fig. 2. General structure of processes of interaction of the verbal level of description of the subject area, the formal level of description of the subject area and machine-interpreted description of the subject area at the level of computer ontology in the systems of e-learning

Figure 2 gives a generalized structure of processes of interactions between the verbal level of the description of the subject area of the academic discipline, the formal level of description of the subject area and the description of the subject area at the level of computer 
ontology, which is implemented through the formalization, interpretation, encoding and decoding in the computer-ontology development environment.

We note that all the above axiomatic systems of representation of statements are isomorphic to each other, since there is a mutually unequivocal correspondence between their elements and the preservation of the corresponding structures, which is provided by the bijective functions of interpretation $f_{S}^{I}(\cdot)$, formalization $f_{S}^{\text {Form }}(\cdot)$, coding $f_{S}^{\text {Cod }}(\cdot)$ and decoding $f_{S}^{\text {Decod }}(\cdot)$.

Thus, the axiomatic-deductive fundamental core of the content of the academic discipline is given by the isomorphic systems considered above, which can be grouped in the form of Table 4.

Table 1.

The system of isomorphic content, formal and machine-interpreted descriptions of the logical-semantic core of the content of the academic discipline, organized on the basis of axiomatic-deductive strategy

\begin{tabular}{|c|c|}
\hline $\begin{array}{l}\text { The terminology-conceptual apparatus of } \\
\text { the core of the content }\end{array}$ & $\begin{array}{c}\text { A system of truthful statements of the core } \\
\text { of the content }\end{array}$ \\
\hline $\begin{array}{c}\begin{array}{c}\text { The content form of presentation of the } \\
\text { terminological and conceptual } \\
\text { apparatus }\end{array} \\
\mathbf{A S}_{C V}=\left\{\mathbf{A I C}_{V}, \mathbf{T C}_{V}, \mathbf{B C} \mathbf{C}_{V}, \text { Ruls_for_C } \mathbf{C}_{V}\right\}\end{array}$ & $\begin{array}{c}\text { A content form of representation of the set of } \\
\text { statements } \\
\mathbf{A S}_{S V}=\left\{\mathbf{A I S}_{V}, \mathbf{T S}_{V}, \mathbf{A S}_{V}, \mathbf{R u l s \_ f o r} \_\mathbf{S}_{V}\right\}\end{array}$ \\
\hline 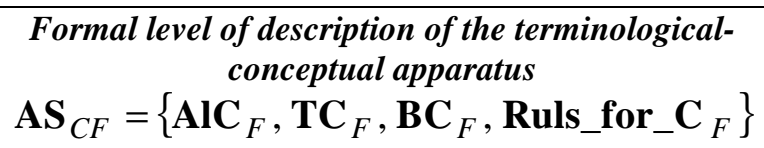 & $\begin{array}{c}\text { Formal level of description of the group of } \\
\text { statements } \\
\mathbf{A S}_{S F}=\left\{\mathrm{AIS}_{F}, \mathbf{T S}_{F}, \mathbf{A S} \mathbf{S}_{F}, \text { Ruls_for_S } \mathbf{S}_{F}\right\}\end{array}$ \\
\hline $\begin{array}{c}\text { Machine-interpreted form of description of the } \\
\text { terminology-conceptual apparatus as an ontology } \\
\mathbf{A S}_{C O}=\left\{\mathbf{A l C}_{O}, \mathbf{T C}_{O}, \mathbf{B C}_{O}, \mathbf{R u l s} \text { for_C }_{O}\right\}\end{array}$ & $\begin{array}{c}\text { Machine-interpreted form of description of } \\
\text { statements in systems of e-learning } \\
\mathbf{A S}_{S E L}=\left\{\mathbf{A I S}_{E L}, \mathbf{T S}_{E L}, \mathbf{A S _ { E L }}, \text { Ruls_for_S }_{E L}\right.\end{array}$ \\
\hline
\end{tabular}

Taxonomically oriented substrategy of deployment of content of the academic discipline

We note that the fundamental core of academic content contains concepts and judgments of the academic discipline that relate to its most general abstract semantic levels. However, in view of the need to ensure a strictly logical transition from abstract general concepts and statements of the academic discipline to the concepts and assertions of a lower level of universality and abstraction, including the specific concepts and assertions of the academic discipline, it is appropriate to develop a taxonomically oriented substrategy for the deployment of content in the academic discipline. Such taxonomically oriented strategy is based on the multiple use of generic-type relations and operations of the division of common concepts $\mathbf{B C} \mathbf{C}_{V}=\left\{C_{V_{1}}, C_{V_{2}}, \ldots, C_{V_{N}}\right\}$ of the academic discipline, as well as the generation of derivative statements as predicates, given on elements of the taxonomy of concepts.

Depending on the number of selected features of the division of the basic concept, it is possible to generate several taxonomies of concepts that are in the generic-type relations and their volume is part of the scope of the basic concept. Before beginning the implementation of a taxonomically oriented strategy of the deployment of content of a academic discipline, it is necessary to clearly outline (generate) the set of all taxonomies in respect of which such a strategy will be implemented. A more detailed description of the taxonomically oriented substrategy of the deployment of content requires a separate scientific paper and is not covered here. 
An example of the implementation of elements of the axiomatic-deductive strategy of organizing the content core of the academic discipline "Computer Logic" in the Protégé environment using the language of describing the ontology OWL

As an example of applying the proposed axiomatic-deductive strategy for organizing the content of the academic discipline using the ontological approach, consider the elements of the semantic space of the academic discipline "Computer Logic" and their representation in the Protégé environment using the language of the description of ontology OWL, which allows using the built-in mechanisms of logical derivations and maintaining the correctness of taxonomic connections between concepts, making it possible to create complex concepts from simpler ones.

The necessary stage of development of the logical-semantic core of the academic discipline "Computer Logic" is a clear definition of its subject area, the definition of basic primary concepts and axiomatic statements. It is important to establish the relation between the concepts of "computer logic", "logic", "formal logic", "mathematical logic", etc. Therefore, the basic concepts related to the term "logic" are given clear definitions and form a set of taxonomies of these concepts, clearly indicating the place of the term "computer logic", which will satisfy the requirement of coherence of academic content. In particular, under the term "logic" it is appropriate to understand the group of fundamental, essential, attributive laws (patterns, structures) of the internal structure (architecture), functioning and evolution (creation, formation, organization, creation, development) of a certain class of systems (phenomena, processes).

Since the concept of "Logic" refers to the fundamental laws of the internal structure (architecture), the functioning and evolution (generation, formation, organization, creation, development) of a certain class of systems, then: 1) the group of essential laws relating to the internal structure (architecture) of this class of systems can rightly be called the architectural logic of systems; 2) it is appropriate that the group of the essential laws relating to the functioning of this class of systems be termed functional logic systems; 3) it is appropriate that the group of essential laws relating to the generation, formation, organization, creation, development, evolution of this class of systems be termed the evolutionary logic of systems (see Figure 3).

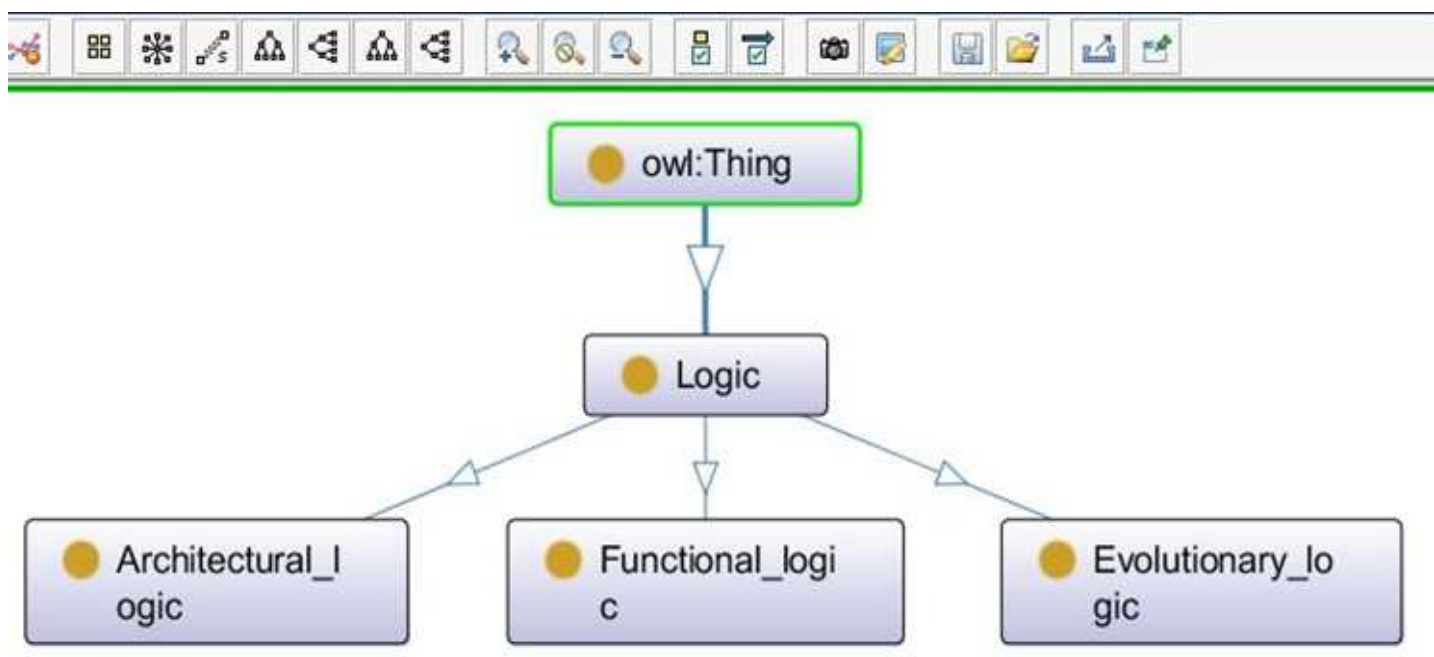

Fig. 3.Division of the concept "Logic" by the type of "part of logic" into the typical concepts "Architectural logic", "Functional logic" and "Evolutionary logic" in the form of taxonomy in the Protégé environment 
On the basis of the group of general concepts and taxonomies of general concepts, the basic axiomatic statements are formulated and the derivative concepts of the lower level of the academic discipline "Computer Logic" are defined, which forms the basis for the organization of its content.

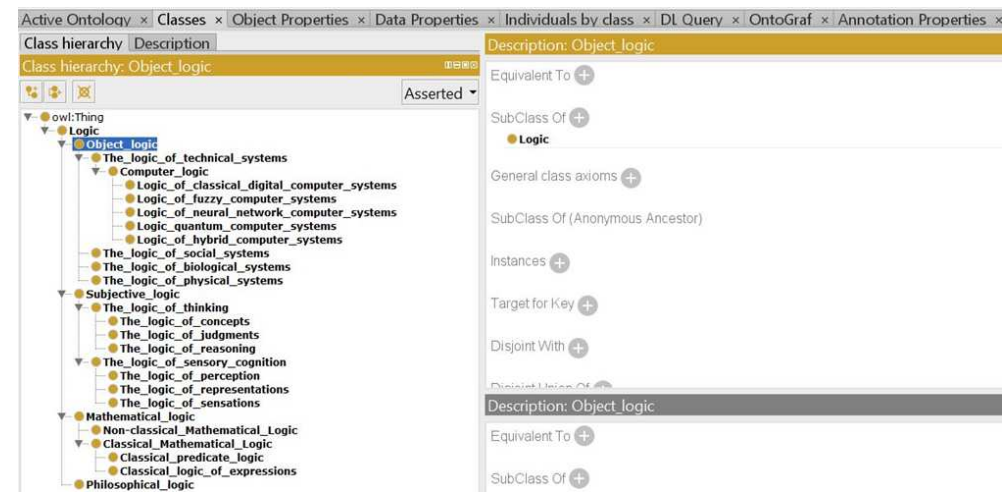

Fig.4. A fragment of the glossary and taxonomy of the academic discipline "Computer Logic" as a component of its ontology in the Protégé environment.

The above metadisciplinary concepts, general (basic and derivative) concepts and concepts of lower level of generality are organized in the glossary and taxonomy of the concepts of the discipline "Computer Logic". A fragment of the glossary of taxosonomy of the discipline "Computer Logic" as a component of its ontology is shown in Figure 4.

\section{CONCLUSION AND PROSPECTS FOR FURTHER RESEARCH}

The transition to distance learning technology raises the need for using the important property of systems of axiomatic statements - their consistency. The advantages of the ontological approach for this purpose have been demonstrated in the previous studies. The authors proposed an axiomatic and deductive strategy for the formation of the discipline content laying ontological approach into the basis. In this case, the important property of the systems of axiomatic statements is used and which is their consistency. Due to this approach an effective formation of the terminology and conceptual apparatus of the discipline, its axiomatic concepts is achieved.

The mathematical structures have been developed for the formalization of the description of the axiomatic-deductive strategy proposed for the organization of general statements of the discipline. It describes the taxonomically oriented substrategy and the deployment of the discipline content. This approach provides a transition from the content form of representation of the discipline chapters to their deployment with the help of artificial languages, typical for mathematical logic.

The research has shown that the use of descriptive logic facilitates the formalization of the procedure, which consists in transformation of the educational content, presented in the axiomatic informal system in information product, created in axiomatic formal system. The achievement of such a transition is due to the description and detalization of the abstract logical and semantic core of the discipline with the help of mathematical structures. This provides the possibility of a logical transition from abstract general concepts to the concepts of lower level of universality.

The developed mathematical structures facilitate the analysis procedures of the relationship between the verbal level of description of the discipline content and description of its subject area at the level of ontology. Thus, the unification of the processes of formalization, interpretation, coding and transcoding of the discipline content in the 
framework of the development of computer ontology is achieved, as demonstrated by an example of the creation of glossary elements and the taxonomy of the concepts of the discipline "Computer Logic" in the Protégé environment using the OWL ontology description language.

In further research it is envisaged to form the basic concepts of axiomatic and deductive strategy of knowledge organization and text course, which is located in the system of elearning, to analyze connections between concepts on the basis of ontological presentation of knowledge, to allocate metadisciplinary logical and semantic essence of the semantic space of the course.

This will contribute to the formation of an axiomatic group of knowledge that will play the role of an axiomatic basis in the structure of the field in order to study the semantic space course and a taxonomically oriented substrate that provides a logical transition from concepts to abstractions.

\section{REFERENCES (TRANSLATED AND TRANSLITERATED)}

[1] Howard Hills. Individual Preferences in e-Learning. London, Routledge, 2017, 192 (in English).

[2] Said S.Al-Gahtani, "Empirical investigation of e-learning acceptance and assimilation: A structural equation model", in Applied Computing and Informatics. vol. 12, iss. 1, pp. 27-50, 2016 (in English).

[3] A.K.M. NajmulIslam, "E-learning system use and its outcomes: Moderating role of perceived compatibility", in Telematics and Informatics, vol. 33, iss. 1, pp. 48-55, 2016 (in English).

[4] Huong May, "Truong. Integrating learning styles and adaptive e-learning system: Current developments, problems and opportunities", in Computers in Human Behavior, vol. 55, part B, pp. 1185-1193, 2016 (in English).

[5] Yao-Ting Sunga, Kuo-En Chang, Tzu-Chien Liu, "The effects of integrating mobile devices with teaching and learning on students' learning performance: A meta-analysis and research synthesis", in Computers \& Education, vol. 94, pp. 252-275, 2016 (in English).

[6] H. Barros, A. Silva, E. Costa, I. I. Bittencourt, O. Holanda, and L. Sales, "Steps, techniques, and technologies for the development of intelligent applications based on Semantic Web Services: A case study in e-learning systems," in Engineering Applications of Artificial Intelligence, № 24, pp. 1355-1367, 2011 (in English).

[7] S. Isotani, R. Mizoguchi, S. Isotani, O. M. Capeli, N. Isotani, A. R. P. L. de Albuquerque, I. I. Bittencourt, and P. Jaques, "A Semantic Web-based authoring tool to facilitate the planning of collaborative learning scenarios compliant with learning theories," in Computers \& Education, vol. 63, № 10, pp. 267-284, 2013 (in English).

[8] L. Rui and D. Maode, "A Research on E - learning resources construction based on semantic Web," in Physics Procedia, vol. 25, № 10, pp. 1715-1719, 2012 (in English).

[9] V. J. Shute and D. Zapata-Rivera, "Adaptive Educational Systems," in Adaptive technologies for training and education, №. 1, pp. 5-27, 2011. (in English).

[10] G. Vega-Gorgojo, M. L. Bote-Lorenzo, J. I. Asensio-Pérez, E. Gómez-Sánchez, Y. A. Dimitriadis, and I. M. Jorrín-Abellán, "Semantic search of tools for collaborative learning with the Ontological search system," in Computers \& Education, vol. 54, № 4, pp. 835-848, 2010 (in English).

[11] E. Junuz, "Preparation of the learning content for semantic e-learning environment," in Procedia - Social and Behavioral Sciences, vol. 1, № 1, pp. 824-828, 2009 (in English).

[12] Serhii Lupenko, Volodymyr Pasichnyk, and Nataliya Kunanets, "Axiomatic-deductive strategy of the organization of the content of academic discipline in the field of information technologies using the ontological approach," in Proc. of the XIII-th International scientific and technical conference Computer Science and Information Technologies CSIT 2018, Lviv, Ukraine, 2017 (in English).

[13] Serhii Lupenko, Volodymyr Pasichnyk, and Nataliya Kunanets "Organization of the content of academic discipline in the field of information technologies using ontological approach," in Advances in Intelligent Systems and Computing, vol. 869, 2018 (in English).

[14] V. Kut, N. Kunanets, V. Pasichnik, and V. Tomashevskyi, "The procedures for the selection of knowledge representation methods in the "virtual university" distance learning system," in Advances in Computer Science for Engineering and Education, vol. 754, pp. 713-723, 2018 (in English). 


\title{
АКСІОМАТИЧНА ДЕДУКТИВНА СТРАТЕГІЯ ФОРМУВАННЯ НАВЧАЛЬНОӤ ДИСЦИПЛІНИ В ГАЛУЗІ ІНФОРМАЦІЙНИХ ТЕХНОЛОГІЙ
}

\author{
Лупенко Сергій Анатолійович \\ доктор технічних наук, професор кафедри комп'ютерних систем та мереж \\ Тернопільський національний університет ім. Івана Пулюя, м.Тернопіль, Україна \\ ORCID ID 0000-0002-6559-0721 \\ lupenko.san@gmail.com \\ Пасічник Володимир Володимирович \\ доктор технічних наук, професор кафедри інформаційних систем і мереж \\ Національний університет «Львівська політехніка», м. Львів, Україна \\ ORCID ID 0000-00002-5231-6395 \\ vpasichnyk@gmail.com
}

\section{Кунанець Наталія Едуардівна}

доктор наук із соціальних комунікацій, професор кафедри інформаційних систем і мереж

Національний університет «Львівська політехніка», м. Львів, Україна

ORCID ID 0000-0003-3007-2462

nek.lviv@gmail.com

\begin{abstract}
Анотація. У статті представлена аксіоматично-дедуктивна стратегія організації змісту навчальної дисципліни за допомогою онтологічного підходу в системах електронного навчання в галузі інформаційних технологій. Авторами враховано, що необхідною властивістю системи аксіоматичних висловлювань $\epsilon$ їх узгодженість. На основі аксіоматично-дедуктивної стратегії запропоновано нові підходи до формування змісту навчальної дисципліни. Доведено, що система коректних викладів навчальної дисципліни спирається на її терміно-концептуальний апарат, зокрема аксіоматичні висловлювання. У статті представлено розроблені математичні структури, що описують аксіоматичнодедуктивну субстратегію організації загальних положень академічної дисципліни та таксономічно орієнтовану субстратегію розгортання змісту навчальної дисципліни. У такий спосіб забезпечується перехід від змістовної форми подання набору положень академічної дисципліни до його подання за допомогою штучних мов математичної логіки. Використання описової логіки забезпечує формалізацію процедури відображення аксіоматичної неформальної системи в аксіоматичній формальній системі. Математичні структури описують і деталізують абстрактне логіко-семантичне ядро академічної дисципліни у вигляді групи аксіоматичних систем. Відзначено, що основне ядро змісту академічної дисципліни містить їі основні поняття та судження. Водночас забезпечується строго логічний перехід від абстрактних загальних понять та висловлювань до понять та тверджень нижчого рівня універсальності та абстракції. Зазначено, що для розміщення змісту академічної дисципліни доцільно розробити таксономічно орієнтовану субстратегію, яка базується на багаторазовому застосуванні. Математичні структури дозволяють провести аналіз узагальненої структури процесів взаємодії словесного рівня опису предметної галузі навчальної дисципліни, формального рівня опису предметної галузі та опису предметної галузі на рівні комп'ютерної онтології, яка здійснюється шляхом формалізації, інтерпретації, кодування та декодування в середовищі розробки комп'ютерної онтології. Як приклад застосування запропонованої аксіоматично-дедуктивної стратегії були розроблені елементи глосарія та таксономії концепцій дисципліни "Комп'ютерна логіка", які реалізовуються в середовищі Protégé за допомогою мови опису онтології OWL.
\end{abstract}

Ключові слова: система електронного навчання; аксіоматично-дедуктивна система; онтологія; онтологічний підхід. 


\title{
АКСИОМАТИЧЕСКАЯ ДЕДУКТИВНАЯ СТРАТЕГИЯ ФОРМИРОВАНИЯ УЧЕБНОЙ ДИСЦИПЛИНЫ В ОБЛАСТИ ИНФОРМАЦИОННЫХ ТЕХНОЛОГИЙ
}

\author{
Лупенко Сергей Анатольевич \\ доктор технических наук, профессор кафедры компьютерных систем и сетей \\ Тернопольский национальный университет им. Ивана Пулюя, г.Тернополь, Украина \\ ORCID ID 0000-0002-6559-0721 \\ lupenko.san@gmail.com
}

Пасичник Владимир Владимирович

доктор технических наук, профессор кафедры информационных систем и сетей Национальный университет «Львовская политехника», г. Львов, Украина

ORCID ID 0000-00002-5231-6395

vpasichnyk@gmail.com

\section{Кунанец Наталия Эдуардовна}

доктор наук по социальным коммуникациям, профессор кафедры информационных систем и сетей Национальный университет «Львовская политехника», г. Львов, Украина

ORCID ID 0000-0003-3007-2462

nek.lviv@gmail.com

\begin{abstract}
Аннотация. В статье представлена аксиоматически-дедуктивная стратегия организации содержания учебной дисциплины с помощью онтологического подхода в системах электронного обучения в области информационных технологий. Авторами учтено, что необходимым свойством системы аксиоматических высказываний является их согласованность. На основе аксиоматически-дедуктивной стратегии предложены новые подходы к формированию содержания учебной дисциплины. Доказано, что система корректных изложений учебной дисциплины опирается на ее термино-концептуальный аппарат, в том числе аксиоматические высказывания. В статье представлены разработанные математические структуры, описывающие аксиоматически-дедуктивную субтратегию организации общих положений академической дисциплины и таксономически ориентированную субстратегию развертывания содержания учебной дисциплины. Таким образом обеспечивается переход от содержательной формы представления набора положений академической дисциплины до его представления с помощью искусственных языков математической логики. Использование описательной логики обеспечивает формализацию процедуры отображения аксиоматической неформальной системы в аксиоматической формальной системе. Математические структуры описывают и детализируют абстрактное логико-семантическое ядро академической дисциплины в виде группы аксиоматических систем. Отмечено, что основное ядро содержания академической дисциплины содержит ее основные понятия и суждения. При этом обеспечивается строго логический переход от абстрактных общих понятий и высказываний к понятиям и утверждениям низшего уровня универсальности и абстракции. Отмечено, что для размещения содержания академической дисциплины целесообразно разработать таксономически ориентированную субстратегию, основанную на многократном применении. Математические структуры позволяют провести анализ обобщенной структуры процессов взаимодействия словесного уровня описания предметной области учебной дисциплины, формального уровня описания предметной области и описания предметной области на уровне компьютерной онтологии, которая осуществляется путем формализации, интерпретации, кодирования и декодирования в среде разработки компьютерной онтологии. В качестве примера применения предложенной аксиоматическидедуктивной стратегии были разработаны элементы глоссария и таксономии концепций дисциплины "Компьютерная логика", которые воплощаются в среде Protégé с помощью языка описания онтологии OWL.
\end{abstract}

Ключевые слова: система электронного обучения; аксиоматическая дедуктивная система; онтология; онтологический подход.

\section{$(\mathrm{cc}) \mathrm{BY}-\mathrm{NC}-\mathrm{SA}$}

This work is licensed under Creative Commons Attribution-NonCommercial-ShareAlike 4.0 International License. 